\title{
THE ALLEGED MISCARRIAGES OF CATHERINE OF ARAGON AND ANNE BOLEYN
}

by

\section{SIR JOHN DEWHURST*}

THE birth to a queen of England of a surviving child has, for the most part, been an event accurately recorded by contemporary chroniclers for the last 500 years. But if the child did not survive, detailed information was often lacking; the sex was generally stated, but whether the infant was stillborn or died soon after birth, whether "soon after birth" meant hours or days, and whether the birth was premature or not, are matters about which precise information is often not available.

If the queen miscarried, the documentation of the event was even less reliable, for a variety of reasons. The term "miscarriage" was, in former times, not used as we would use it now to refer to the expulsion of the child from the womb before twentyeight weeks of pregnancy, but was very loosely used to describe the birth of a dead child whether this occurred before or after viability. Thus a queen might be reported to have miscarried when, in reality, she had had a premature stillbirth. Second, if the miscarriage had been very early in pregnancy, as many are, the physicians might have been uncertain that a miscarriage had actually occurred or, if they were certain, the event may not have been announced outside the immediate family circle. Third, any indisposition the queen may have suffered was believed to be concerned with a pregnancy; when no child was subsequently born, it was concluded that she must have had a miscarriage. Very soon, the conclusion that she "must have had" became an assertion that she "had" miscarried. Historians, sometimes of the highest repute, and other historical writers have tended to accept such evidence somewhat uncritically, so lending the weight of their authority to what was initially mere rumour.

Two of England's queens who have particularly suffered in this respect are Catherine of Aragon and Anne Boleyn. A close examination of the evidence does not suggest a series of miscarriages in either, as has been commonly asserted.

Catherine of Aragon's childbearing history has been variously reported by historians. Scarisbrick' credits her with "several miscarriages, three infants who were either stillborn or died immediately after birth (two of them males), two infants who died within a few weeks of birth (one of them a boy) and one girl, Princess Mary"; this must mean a total of at least nine pregnancies since "several miscarriages" can hardly

\footnotetext{
* Professor Sir John Dewhurst, FRCOG, FRCSE, Queen Charlotte's Maternity Hospital, Goldhawk Road, London W6 0XG.
}

1 J. J. Scarisbrick, Henry VIII, London, Eyre \& Spottiswood, 1968, p. 150. 


\section{Sir John Dewhurst}

be regarded as referring to less than three. Chapman ${ }^{2}$ gives the total of Catherine's pregnancies as seven, one of which resulted in one live child and six that ended either in miscarriages or stillbirths. Williams ${ }^{3}$ is imprecise about the final total, but, commenting upon the attention Henry lavished on his wife as early as the second year of their marriage, remarks that Henry was "mindful of earlier miscarriages". Pollard," referring to events about the year 1517 , wrote, "It is probable that about this time the Queen had various miscarriages"; "various" like "several" cannot refer to less than three.

If, therefore, we consider at this point merely these last two comments concerning "earlier" miscarriages around 1510 and "various" ones about 1517, at least five miscarriages are being postulated.

Not all historians accept these figures. Bowle ${ }^{5}$ rejects the alleged miscarriages around 1517 as inventions of Pollard, inventions that Chamberlin ${ }^{6}$ goes so far as to describe as mischievous. These two writers also discount an additional son, who was "no sooner christened than dead". Pollard alleges that he was born in 1514, ${ }^{26}$ thus bringing the total of Catherine's pregnancies, in his opinion, to at least ten! Bowle, by contrast, accepts only six pregnancies for Catherine, which ended in the birth of Mary who lived to be middle-aged, a boy who lived for fifty-two days, and four children who were stillborn or who died very soon after birth. Chamberlin accepts these same six pregnancies, disregarding other possible ones because of insufficient evidence, a view which Neale ${ }^{7}$ appears to accept. With such differing views being expressed, a careful reappraisal of the evidence is clearly necessary.

The Queen's first pregnancy ended on 31 January 1510, thirty-three weeks after her marriage, when she gave birth to a stillborn daughter. This information did not emerge until four months afterwards when, on 25 May on Catherine's instructions, her chancellor, Diego Fernandez $z^{8}$ wrote to her father King Ferdinand in these words: "The last day of January in the morning her Highness brought forth a daughter . . . this affair was so secret that no-one knew it until now except the King my lord, two Spanish women, a physician and I." Here was a remarkable circumstance, but the reason for the secrecy was more remarkable still. "The physician said", continued the letter, "that her Highness remained pregnant with another child and it was believed and kept secret"! Two days after the despatch of her chancellor's letter, Catherine" herself wrote to her father confirming that she "miscarried a dead daughter and because it was considered here an ill omen I did not write before to tell your Highness". That the secret was well kept, there can be no doubt. On 20 April, Andrea Badoer, ${ }^{10}$ the Venetian ambassador, reported that "His [the king's] wife has not yet

${ }^{2}$ Hester W. Chapman, Anne Boleyn, London, Jonathan Cape, 1974, pp. 41-42.

${ }^{3}$ Neville Williams, Henry VIII and his court, London, Weidenfeld \& Nicolson, 1971, p. 47.

4A. F. Pollard, Henry VIII, London, Longman Green, 1925, p. 12.

'John Bowle, Henry VIII, Newton Abbot, David \& Charles, 1964, p. 159.

- F. Chamberlin, The private character of Henry VIII, London, Bodley Head, 1932, pp. 120-126.

'Sir John E. Neale, Queen Elizabeth, Harmondsworth, Penguin Books, 1960, p. 10.

- Calendar of letters, despatches and state papers relating to the negotiations between England and Spain preserved in the archives at Simancas and elsewhere (CSP Span.), edited by Pascual de Gayangos, supplements to vols. I and II, item 7, p. 34.

- Public Record Office, Spanish Transactions Series 1, 5, f. 119.

${ }^{10}$ Quoted by Chamberlin, op. cit., note 6 above, p. 108. 


\section{The alleged miscarriages of Catherine of Aragon and Anne Boleyn}

been delivered". Peter Martyr, ${ }^{11}$ the historian, who was at the time living with the Spanish royal family, wrote that in early April "News reached the King from England . . . that the Queen of that island, his daughter, was about to be delivered of a child being then in her ninth month", Even Caroz, ${ }^{12}$ the Spanish ambassador in London, leaves no doubt that he had been ignorant of the stillbirth that had occurred on 31 January.

The Queen was not carrying another child, but she did become pregnant again quite soon. Fernandez included the news of it in his letter to King Ferdinand in these words - "It has pleased the Lord to be her physician . . . and by His infinite mercy has permitted her to be pregnant again." Catherine herself informed Caroz, on 20 May, that she was "not pregnant for more than nine weeks". "She does not wish me to write to His Highness [the King]", wrote Caroz, "until she sends to me because she wishes to wait until the pregnancy is well established in the third month so that the good news of the pregnancy may soften the annoyance of his Highness at what has passed". Nine weeks on 20 May corresponds closely with the eventual outcome of this pregnancy, which was a successful birth of a son on 1 January 1511 .

The birth was received with great celebrations. Bells rang, bonfires were lighted, guns were fired, and "207 lbs of gunpowder at 4 pence the pound" was "shot ... in the Tower of London"13 to welcome the new prince. In the midst of the Christmas festivities and excitement, the boy was christened Henry in the presence of the ambassadors to the Pope, France, Spain, and Venice, who afterwards visited and congratulated the Queen. Henry made a special pilgrimage to Walsingham to offer thanks to the Blessed Virgin and, once Catherine was well enough to join in the festivities, a fabulous tournament was held at Westminster. But all the joy and celebration was shortlived. The tournament had barely concluded when the young prince was taken ill at Richmond and died on 22 February, fifty-two days after his birth. A gathering of nobles for the celebration of a triumphant birth became one of lamentation for a tragic death.

There was, therefore, no time during 1509 and 1510 for "earlier miscarriages". The word miscarriage might loosely, if inaccurately, be applied to the birth of a stillborn daughter on 31 January 1510, only thirty-three weeks after Catherine's marriage; she herself used it when she wrote that she had "miscarried a dead daughter", but there was clearly no time for her to have squeezed in another pregnancy in those years.

Catherine's next confinement occurred in 1513, although we know little of the events that took place. On 17 September, she gave birth to a son who died, but it is uncertain if he was stillborn or lived a short time. The Venetian Calendar of State Papers $^{14}$ records that the child was alive at birth: "a male heir was born to the King of England and will inherit the crown, the other son having died". The same conclusion can be drawn from the only other contemporary reference to this birth: "The Queen of England has given birth to a son", wrote Bannisius, the Imperial agent, to Lord

\footnotetext{
11 Opus Epistolarum Petri Martyris Anglerii, 1530 ed., fol. XCV, vi, nonas Maii M.D. [2 May 1510].

12 CSP Span, supplements to vols. I and II, item 8, p. 36.

${ }^{13}$ Letters and papers foreign and domestic of the reign of Henry VIII, catalogued by James Gairdner, vol. I, part I, item 1463 (1 November 1511).

14 Calendar of state papers and manuscripts relating to English affairs existing in the archives and collections of Venice (CSP Venice), edited by Rawdon Brown, vol. II, item 329, p. 140.
} 


\section{Sir John Dewhurst}

Albert of Carpi. ${ }^{15}$ The absence of other references to the birth in documents and state papers lends support to the view that the boy must have died very soon after birth. There is no record of the birth being premature but, since the King was in France when it occurred and was not due to return until 21 October, labour may have begun sooner than expected - it seems unlikely that Henry would have wished to be absent when his child was born.

Catherine conceived her fourth pregnancy quite quickly, and by the summer of the following year it was evident to several foreign observers at court who reported it in their correspondence. The most important of these accounts, which we will consider again later, are from a court official, De Plein, who wrote to Margaret of Savoy on 30 June, and Di Favri, an attaché at the Venetian embassy, who wrote to a colleague in August. "It is said that the Queen is with child and, as far as I know, and can see, it is so", reported De Plein. ${ }^{16}$ "After the King", wrote Di Favri, ${ }^{17}$ "came the Queen who is pregnant clad in ash-coloured satin with chains and jewels and on her head a cap of cloth of gold covering the ears in the Venetian fashion". Regrettably, we do not know precisely when the Queen was confined nor, indeed, whether the infant was stillborn or lived a short time. Badoer, ${ }^{18}$ the Venetian ambassador, wrote to his senate in November that "The Queen has been delivered of a stillborn male child of eight months to the very great grief of the whole court". The chronicler Holinshed"19 reported that, "In November the Queen was delivered of a prince which lived not long after", whilst Stow wrote, "In the meantime, to Whit, the month of November, the $Q$ was delivered of a prince which lived not long after".

The interval between these two children was too short for any intervening pregnancy, but the interval between the births of the second and third was two years and nine months, which would have provided ample opportunity for a miscarriage to have occurred. Naturally, since the Queen had, by that time, borne two children and both were dead, everyone at court would have been most anxious for her to conceive again. It is hardly surprising, therefore, that we find Cardinal Wolsey ${ }^{21}$ writing to Richard Fox, Bishop of Winchester, on 11 September 1511 to report that, "It is thought that the Queen is with child". Since there is no other report of a pregnancy at that time, the phrase remains unsubstantiated and must be discounted as unfounded rumour; it is certainly quite insufficient evidence on which to postulate a miscarriage.

Setting this unsupported "thought" aside, therefore, we come to the Queen's fifth and only successful pregnancy. Catherine bore a daughter at Greenwich palace on 18 February 1516. The child was christened Mary three days later. Emotions fluctuated between elation that the infant was alive and well, and disappointment that it was not a boy. Henry, with more optimism than he can have felt, told the Venetian ambassador "We are both young and by God's grace boys will follow". Boys did not follow and Catherine was not to bear any other living child. Her sixth and last confine-

${ }^{15}$ Quote by Chamberlin, op. cit., note 6 above, p. 118.

${ }^{16}$ Lettres du Roy Louis XII, vol. IV, p. 341.

17 CSP Venice, vol. II, item 505, p. 198.

18 Ibid., item 555, p. 223.

19 Raphael Holinshed, Chronicles 3, p. 834.

20 John Stow, The annals of England, p. 497.

21 J. Grove, Life and times of Cardinal Wolsey, London, 1742, p. 152. 


\section{The alleged miscarriages of Catherine of Aragon and Anne Boleyn}

ment was announced by Henry in a personal letter to Cardinal Wolsey on 1 July 1518:22 "Two things there be which be so secret that they cause me at this time to write to you myself; the one is that I trust the Queen my wife to be with child". But this pregnancy, too, ended in a stillbirth on 10 November 1518 . The child, it seems, was premature: "The Queen has been delivered in her eighth month of a stillborn daughter to the great sorrow of the nation at large", ${ }^{23}$ wrote the Venetian ambassador Giustiniano. "Never had the kingdom so anxiously desired anything as it did a prince". ${ }^{24}$

Between 18 February 1516 and 10 November 1518 is presumably the interval that Pollard referred to when he wrote that "It is probable that about this time the Queen had various miscarriages". "He made reference to a report in August 1517 that Catherine was pregnant again. The Venetian, Chieregado, wrote to the Marquis of Mantua and his letter contained the words "the Queen has lately been unwell, but by the grace of God is convalescent and is supposed to be pregnant". ${ }^{25}$ Pollard admitted that "nothing more is heard of the matter", but then, instead of dismissing it as rumour, which would seem to be the proper course since the "supposed" pregnancy was unconfirmed, went on to postulate "various miscarriages" upon no evidence whatever. Chamberlin's view that this statement was mischievous does not seem too strong a word.

Pollard, unfortunately, actually saddled Catherine with still another unsuccessful pregnancy which was a physical impossibility. His claim that Catherine had borne a son in June 1514 - a son who was "no sooner christened than dead"26 - rested upon a phrase in a letter from Sir Richard Wingfield to Cardinal Wolsey. ${ }^{27}$ The original of the letter had been damaged with other documents in a fire in Ashburnham House, Westminster School, in 1731, and all that remained of the phrase which Pollard took to refer to the christening of the King's son was "sacrying of the King's new S -". In reality, this referred to the hallowing or dedication of the King's ship Henri Grace $a$ Dieu, to which Di Favri referred in these words "On Tuesday 13 June the King caused a very fine ship of his to be blessed ... many masses were said on board including high mass".

Several unassailable facts indicate the impossibility of the Queen having had a baby in June 1514. As we have already noted, she was visibly pregnant to De Plein at the end of that month and to Di Favri in August, and was delivered of a son of eight months gestation in November. The delivery of a child who was christened at once and died in mid-June was impossible.

What is there left, therefore, to support "several" or "various" miscarriages in addition to the six pregnancies of which the outcome is known? Merely a phrase in one letter that Catherine was "thought" to be pregnant and in another that she was "supposed" to be pregnant. In the abence of other evidence, these can surely be

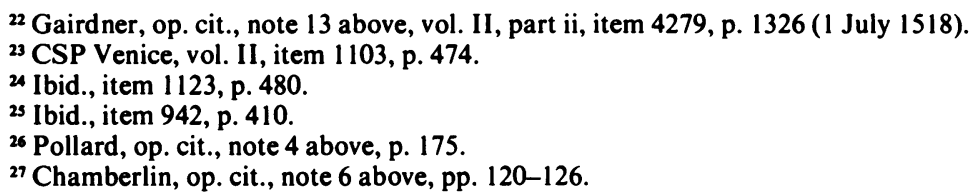




\section{Sir John Dewhurst}

dismissed as unsupported rumour and Catherine relieved of the burden of her alleged miscarriages.

A consideration of the views expressed about Anne Boleyn's pregnancies reveals similar discrepancies. That Anne gave birth to Elizabeth on 7 September 1533 is not in dispute. Nor is there dispute about the production of a male foetus in January $1536,{ }^{28}$ although how far advanced in pregnancy she may have been at that time is not agreed.

In addition to these two pregnancies, a varying number of miscarriages has been postulated. Professor Elton ${ }^{29}$ uses the phrase "the dreary tale of miscarriages was resumed" after the birth of Elizabeth and, although this is not precise as to number, it gives the impression of three or four or perhaps even more.

Bruce $^{30}$ has written that "during the first six months of 1534 she appears to have had one miscarriage after another". It is scarcely "conceivable" for a woman to have more than three miscarriages within a six-months period, so this figure can perhaps be accepted as the number being alleged. Chapman ${ }^{31}$ supposes a miscarriage in March 1534, another pregnancy in April, and perhaps a third in July which ended at the beginning of September in "what seems to have been her third miscarriage". This author believes that Anne became pregnant again around mid-June 1535, this pregnancy ending in the seventh month with the birth of a dead son in January 1536. Chamberlin, ${ }^{32}$ however, accepts only two miscarriages for Anne, the first in 1534 and the second in 1535. Again a reappraisal of the evidence seems essential.

When Anne married Henry about 25 January 1533, she was already pregnant and gave birth to Elizabeth on 7 September. The events of the following year are very much disputed. The observations made at the time that relate to a possible pregnancy in 1534 are these. Eustace Chapuys, the ambassador of Charles V, wrote on 28 January 1534 to inform his emperor that Anne was again pregnant. ${ }^{33}$ Chapuys wrote again on 26 February reporting that Henry had told him that Elizabeth was his only heir until a son was born "which he thought would happen soon." 34 A letter sent by George Taylor from Greenwich to Lady Lisle on 27 April told her that "The Queen hath a goodly belly, praying our Lord to send us a prince"' ${ }^{35}$ Early in July, the King sent Anne's brother, Viscount Rochford, to the French King, Francis I, to ask that an intended meeting between the two sovereigns be deferred, since Anne "being so far gone with child she could not cross the sea with the King". ${ }^{36}$ Chapuys makes a later reference to this postponement in a letter of $29 \mathrm{July}$, in which it is clear that he believed Anne to be pregnant; he remarked that she could not be present without postponement "on account of her condition".

\footnotetext{
23 CSP Span., vol. V, part ii, item 17, p. 39.

29 G. R. Elton, England under the Tudors, London, Methuen, 1955, p. 152.

${ }^{30}$ Marie Louise Bruce, Anne Boleyn, London, Collins, 1972, p. 251.

${ }^{31}$ Chapman, op. cit., note 2 above, pp. 161-163.

${ }^{32}$ Chamberlin, op. cit., note 6 above, pp. 160-161.

${ }^{33}$ CSP Span., vol. V, part i, item 7, p. 21.

${ }^{34}$ Gairdner, op. cit., note 13 above, vol. VII, part i, item 232, p. 91.

35 Ibid., item 556, p. 221.

${ }^{36}$ Ibid., item 958, p. 366.
} 


\section{The alleged miscarriages of Catherine of Aragon and Anne Boleyn}

It is remarkable, to say the least, that no details so far discovered refer directly to the outcome of this pregnancy - if indeed it was a pregnancy. Many views have been put forward nonetheless. Chamberlin suggested that since the Queen was "far gone with child" at the beginning of July, the outcome must have been "a miscarriage, not an abortion"; 37 by "miscarriage" he was referring to a pregnancy coming to an end after the conclusion of the fourth month, but before the beginning of the eighth. This view, nonetheless, is pure supposition.

We have noted Bruce's comments ${ }^{30}$ that Anne had one miscarriage after another during the first six months of 1534 and Chapman's statements that there was a miscarriage in March, a new pregnancy in April, another pregnancy in July (presumably preceded by a miscarriage in June) leading to the third miscarriage in September. The evidence just quoted supports none of this. If the Queen had "a goodly belly" when George Taylor wrote in April, ${ }^{35}$ she must have been at least sixteen weeks (four months) pregnant. She cannot, therefore, have had a miscarriage earlier that year. If she had miscarried and become pregnant again in April she would not have had a "goodly belly". Moreover, the only way the Queen could possibly have been "far gone with child" in July was for her pregnancy to have dated from at least the beginning of the year, probably late the previous year. If we accept this evidence of an apparent pregnancy that was "far gone" in July, the Queen cannot have miscarried at all earlier that year.

So what happened to the pregnancy? A stillborn or premature child who died very quickly is a possibility, but there is no reference whatever to such an event. There is, however, a curious reference to the pregnancy in a further letter from Chapuys dated 27 September 1534:38 "Since the King began to doubt whether his lady was enceinte or not, he has renewed and increased the love he formerly had for a beautiful damsel of the court". Why should the King have doubted the Queen's pregnancy except for her failure to go into labour and produce a child? Had Anne miscarried, there would have been no doubt that she had been pregnant, but her failure to produce either an abortion or a child would certainly have led to doubt about the reality of her pregnancy. This failure can best be explained by postulating that Anne's supposed pregnancy was a pseudocyesis. ${ }^{39}$ This curious disorder, which is associated with visible swelling of the abdomen despite the fact that no pregnancy exists, classically occurs in women who are desperate to prove their fertility or who dread the possibility that an unguarded act of intercourse might have led to an unwanted conception. Anne was certainly in the former category, since her very life, literally, depended upon giving the King the son he longed for. If this were so, Anne would not be the only queen of England to be so affected, since both Mary I and Mary II had similar episodes. ${ }^{39}$ Muriel St Clair Byrne, editor of the Lisle letters, also suggests a phantom pregnancy for Anne in $1534,{ }^{40}$ and points out that Honor Lisle was similarly affected in $1536-7$. Neale ${ }^{41}$ is not explicit about a possible pseudocyesis but does appear to reject the notion of a pregnancy "in the summer of 1534", since he wrote "by September Henry knew that it

\footnotetext{
${ }^{37}$ Chamberlin, op. cit., note 6 above, p. 161.

${ }^{38}$ Gairdner, op. cit., note 13 above, vol. VII, part ii, item 1193, p. 463.

${ }^{39}$ Sir John Dewhurst, 'Royal pseudocyesis', History of Medicine, 1980, 8: 12-17.

${ }^{-0}$ Muriel St Clare Byrne, The Lisle letters, Chicago University Press, 1981, vol. I, p. 240.

${ }^{41}$ Neale, op. cit., note 7 above, p. 13.
} 


\section{Sir John Dewhurst}

[the supposed pregnancy] was untrue".

So if we consider the evidence written at the time, we find scarcely any support for a miscarriage and none whatsoever for a series of miscarriages in 1534 . What about 1535? The only evidence for a miscarriage in that year arises from part of a single sentence in a letter written by William Kingston to Lord Lisle on 24 June 1535: "Her Grace has as fair a belly as I have ever seen". ${ }^{42}$ No child is known to have been born from this supposed pregnancy, and a miscarriage has been presumed. In Chamberlin's words, "It would appear reasonable to conclude that she had had a miscarriage and had recovered from it". ${ }^{43}$ Accepting Kingston's letter on its face value, Chamberlin's conclusion does seem reasonable, but the publication of the Lisle correspondence ${ }^{44}$ shows this possible pregnancy in a different light. The editor has dated this letter 1533 or possibly 1534, the former being the more probable. The letters appears to make reference to Sir Christopher Garneys and his wife. Sir Christopher died on October 1534 and was succeeded by Sir Thomas Palmer, who was unmarried. Whether it was written in 1533 or 1534, therefore, the letter can hardly have been written in 1535 and the only evidence of the pregnancy in the summer of that year disappears. If this redating is correct, as seems likely, we have absolutely no reason to presume a miscarriage for Anne in 1535.

Some time in the autumn of that year, however, Anne must have become pregnant, since she miscarried on 27 January 1536, the day of the funeral of Queen Catherine. Chapuys reported the event in a letter to Charles V dated 10 February: "On the day of the interment [of Catherine of Aragon] the concubine [Anne] had an abortion which seemed to be a male child which she had not borne $3 \frac{1}{2}$ months". ${ }^{45}$ However imprecise the term miscarriage may have been when used in former times, Chapuys' reference to a child "which she had not borne $3 \frac{1}{2}$ months" seems to make it clear that Anne lost this child at a comparatively early stage in her pregnancy. Sex would have been visible at $3 \frac{1}{2}$ months, so we need not postulate, because the child was known to be male, that the duration of the pregnancy was more advanced. Chapuys' phrase does not support the suggestion that Anne was in her seventh month when she gave birth to this child.

Thus the Lisle letter relieves Anne of the burden of one alleged miscarriage and careful examination of the evidence surrounding a possible pregnancy in 1534 provides little if any support for any miscarriage that year. She is left with only two pregnancies, one successful and one unsuccessful.

Perhaps the oft-repeated assertions that both Catherine and Anne had a series of miscarriages may be laid to rest.

\footnotetext{
${ }^{42}$ Chamberlin, op. cit., note 6 above, p. 162.

43 Ibid.

44 Byrne, op. cit., note 40 above, vol. I, pp. 477-478.

${ }^{45}$ Gairdner, op. cit., note 13 above, vol. X, item 284, p. 104.
} 